\title{
FACTORS INFLUENCING ELECTRONIC WASTE (E-WASTE) SEPARATION INTENTION OF ELECTRONIC SHOP OWNERS IN BANGLADESH: A CONCEPTUAL MODEL
}

\author{
Ashikur Rahman ${ }^{1 *}$, Teoh Ai Ping ${ }^{1}$, Imran Mahmud² \\ ${ }^{1}$ Graduate School of Business, Universiti Sains Malaysia, Penang, Malaysia \\ 2Department of Information Technology \& Management, Daffodil International University, Dhaka, Bangladesh
}

ABSTRACT - Bangladesh observes the production of approximately 400,000 metric tonnes of ewaste every year. It is expected that it will witness a $20 \%$ increase annually. In order to implement e-waste recycling, it is essential to uncover the influencing factors. In this study, electronic shop owners act as one of the major players responsible for aggregation of e-waste in the country. Based on Value-Belief-Norm Theory, Self Determination Theory and synthesizing relevant literature in the body of knowledge, this paper presents an integrated conceptual model consisting Altruistic values, Egoistic values, Biosphric values, Environmental belief, Personal norm, Intrinsic motivation and Extrinsic motivation, which are predicted to influence e-waste separation intention in Bangladesh. From a practical point of view, this research sheds light on key determinants that affect separation intention, in which practitioners need to consider when developing strategies concerning e-waste management and policies in Bangladesh.

\author{
ARTICLE HISTORY \\ Received:29-11-2019 \\ Accepted:14-1-2020 \\ KEYWORDS \\ Bangladesh \\ E-waste \\ Separation intention \\ Electronic shop owners
}

\section{INTRODUCTION}

"E-waste refers to the reverse supply chain that collects products no longer desired by a given consumer and refurbishes for other consumers, recycles, or otherwise processes wastes," (Step Initiative, 2014). E-waste observes rapid growth in comparison to the other forms of waste in the world (Fu et al., 2018; Oleszek et al., 2018). Nowadays, electronic waste (e-waste) is becoming an alarming issue that concerns the global environment and health inequity. Frequent and excessive production of electronic goods produces a huge amount of global e-waste (Aich et al., 2020). Balde et al., (2017) reported that the global production of e-waste was 44.7 million metric tonnes (MMT) in 2016 and estimated that it would increase to 52.2 MMT by 2021. This upward trend has serious consequences on environmental pollution and has become the root cause of many diseases for human health. This discarded e-waste is usually dumped in open landfills, open water bodies, and on farming land, causing severe health and environmental impacts. (Herat \&Agamuthu, 2012). In the contemporary world, the issue of e-waste has great significance. On one hand, e-waste is a source of toxic elements such as lead, cadmium, mercury, chromium, and poly-brominated biphenyls; while on the other hand, it is also a treasure of precious metals such as iron, copper, aluminum, gold, silver and other valuable metals (Madrigal-Arias et al., 2015).

Table 1. Summary of the number of countries' recycling pattern and legislation presence of e-waste

\begin{tabular}{cccc}
\hline Country & $\begin{array}{c}\text { Presence of Specific E- } \\
\text { waste Legislation }\end{array}$ & $\begin{array}{c}\text { Recycling } \\
\text { pattern }\end{array}$ & References \\
\hline Bangladesh & NO & Informal & (Masud et al.2019; Alam\&Bahauddin 2015) \\
India & YES & Informal & $\begin{array}{c}\text { (Pandey and Govind, 2014; Manomaivibool, 2009). } \\
\text { Pakistan }\end{array}$ \\
Nhina & YES & Informal & (Shaikh et al., 2020; Imran et al., 2017) \\
Japan & YES & $\begin{array}{c}\text { Informal } \\
\text { Formal }\end{array}$ & (Yu et al. 2014; Li et al., 2011; Veenstra et al., \\
Korea & YES & Formal & 2010) \\
& & & $\begin{array}{c}\text { (Xavier and Adenso-Díaz 2015; Kim et al., 2013; } \\
\text { Kahhat et al., 2008). }\end{array}$
\end{tabular}




\begin{tabular}{|c|c|c|c|}
\hline Thailand & NO & Informal & (Manomaivibool and Vassanadumrongdee, 2011 \\
\hline Vietnam & NO & Informal & (Hai et al.2017; Pariatamby and Victor, 2013) \\
\hline Switzerland & YES & Formal & (Duygan and Meylan, 2015) \\
\hline Spain & YES & Formal & (Queiruga et al., 2012). \\
\hline Germany & YES & Formal & (Boldoczki et al., 2020; Widmer et al., 2005). \\
\hline UK & YES & Formal & (Borthakur \& Govind, 2017) \\
\hline Nigeria & NO & Informal & (Nduneseokwu et al., 2017) \\
\hline Ghana & NO & Informal & (Asibey et al., 2020; Oteng-Ababio, 2012) \\
\hline USA & YES & Formal & (Li, 2011; Wagner, 2009) \\
\hline Mexico & NO & Informal & (Garcia et al., 2012) \\
\hline
\end{tabular}

Australia $\quad$ YES Formal $\quad$ (Dias et al., 2018; Davis and Herat, 2010)

Table 1 represents different countries' recycling patterns and the presence of environmental acts. It reflects that countries with the presence of strong environmental acts are more likely to recycle their e-waste formally except India.

Bangladesh is a developing country that graduated from the status of the least developed country to a low middleincome country in 2018 (Kabir \& Khan, 2020). Nnorom and Osibanjo (2008) argued that the e-waste growth rate is higher in developing countries compared to developed countries for three reasons which are faster ICT growth rates, lack of formal recycling system, and weak or no presence of policy and legislation. As an emerging country, Bangladesh concerns more about ICT development. Moreover, easy access to electronic goods at a lower price and increasing the purchasing power of individuals cause frequent use of electronic devices (Mahmud et al., 2020). Bangladesh produces around 400,000 metric tonnes of e-waste annually. Illegally imported e-waste from developed countries and locally produced ewaste are expected to increase by $20 \%$ annually in Bangladesh (Mahmud et al., 2020). The resources that have been identified as accountable for waste production include ship-breaking yards, television sets, mobile phones, dental waste, and household electrical appliances, which have been responsible for producing e-waste. Karim et al. (2014) claimed the absence of specific laws or policies for e-waste management and recycling in Bangladesh is the reason for the inconsistency in data and unavailability of inventory on the amount of e-waste generated, which has been associated with the country.

Among the other waste streams in the solid waste sector, e-waste is increasing approximately three times faster, as reported by Schwarzer et al. (2005). Residents mix up the e-waste generated with municipal solid waste due to a lack of recycling knowledge (Bhat \& Patil, 2014). Safe management of e-waste has drawn much attention in the concurrent days due to toxic substances that are yielded by the e-waste (Alam et al., 2015; Herat \& Agamuthu, 2012). Ramayah and Rahbar (2013) recommended that waste should be separated before being recycled. In order to minimize the portion of waste being dumped at the landfill and increase the recycling rate, Badgie (2010) suggested waste separation as one of the key ways.

In developing countries, the attention to the quantification of the e-waste collected is relatively little. In such countries, the collection of e-waste is mostly operated by the unorganized sector of scrap dealers/traders or peddlers (Shaikh et al., 2020). Therefore, this information remains unexplored and is often excluded from the national statistics regarding waste production. As a result, the quantification of e-waste is now a challenging task in developing countries (Liu et al., 2009). Consequently, there is no proper e-waste recycling management process taken by the Bangladesh government, which causes serious environmental pollution (Islam et al., 2016; Masud et al., 2019). In addition, no restrictions have been imposed on electronic shop owners by the government to limit the e-waste aggregation percentage (Masud et al., 2019). In Bangladesh, inadequate studies have been done to assess the significant factors that might influence e-waste recycling (Mahmud et al.2020; Masud et al., 2019; Islam et al., 2016; San et al., 2016). Earlier studies focused on the respondents such as students, residents, and users on their perspective for measuring e-waste recycling intention. However, limited studies have examined the viewpoint of electronic shop owners (Mahmud et al., 2020).

The purpose of this paper is to employ the Value-Belief-Norm Theory and Self Determination Theory as theoretical support to develop a conceptual model to identify the influencing factors of electronic waste separation intention of electronic shop owners in Bangladesh. This study intends to establish the relationships between small electronic items with the psychological and behavioural consequences of electronic shop owners' e-waste separation intention. 


\section{LITERATURE REVIEW}

\section{Value belief norm theory}

The VBN theory was first developed by Stern et al. (1999). The VBN theory classified pro-environmental behaviours into four different major groups including Activism, non-activist public-sphere, private sphere, and behaviours in organizations (Stern, 2000; Stern et al., 1999). Many researchers tested VBN theory, which has exclusively concentrated on private-sphere pro-environmental behaviours of individuals and consumers (Gkargkavouzi et al., 2019; Li et al., 2018; Onel \& Mukherjee, 2017; Fornara, Pattitoni, Mura, \&Strazzera, 2016; Kim, Lee \& Yang, 2015; Ylä-Mella et al., 2015; Jakovcevic \& Steg, 2013; Henry \& Dietz, 2012; Steg, Dreijerink, \&Abrahamse, 2005; Stern, 2000). However, few studies have been focusing on this theory from a Business manager's point of view (Vanderploeg \& Lee 2019; Papagiannakis \& Lioukas, 2012; Andersson, Shivarajan, \& Blau, 2005). The VBN model concerns a causal chain from values, beliefs, awareness of consequences, an ascription of responsibility, and personal norms to pro-environmental behaviours. Most importantly, each variable in this chain has a direct impact on the next and indirect effect on variables down the line. In addition, personal norms are considered as the principal factors of an individual's predisposition to pro-environmental behaviours (Vanderploeg \& Lee 2019; Gkargkavouzi et al., 2019; Li et al., 2018; Jakovcevic \& Steg, 2013; Kilbourne \& Pickett, 2008; Nordlund \& Garvill, 2002, 2003; Schwartz, 1992; Stern \& Dietz, 1994; Stern et al.,1999). Some researchers also extended the VBN theories by contributing factors including Green trust, Self-identity, Habit, and Subjective norms to demonstrate an individual's environmental behaviour (Choi et al., 2015; Gkargkavouzi et al., 2019). However, a growing number of researchers also modified the VBN theory, excluding awareness of consequences and ascription of responsibility (Andersson et al., 2005; Kim et al., 2015; Ture \& Ganesh, 2014; Whitley et al.,2016; Vanderploeg \& Lee, 2019; Liu et al., 2018). VBN theory has frequently been used on the waste recycling perspective (Li et al., 2018; Ofstad et al., 2017; Onel \& Mukherjee, 2017; Ylä-Mella et al., 2015).

\section{Values}

Values are defined as "underlying orientations held by individual towards the physical environment" (Barr, 2007). Values are general goals that act as a guiding principle in people's lives and affect multiple environmental behaviours (Schwartz, 1992; Steg et al., 2014). Schwartz (1992) developed a typology of values, suggesting ten types of values. Later values are categorized into four major clusters such as Openness to change, Conservation, Self-transcendence (altruistic values), and Self-enhancement (Egoistic values). Personal values here are conceptualized as "the criteria that people use to select and justify actions and to evaluate people and events" (Schwartz, 1992, p. 1). Prior research also has shown that the more strongly an individual subscribes to values such as altruistic, egocentric, biospheric values, the more obvious they are to be engaged toward environmentally sensitive behaviours (Vanderploeg \& Lee (2019). Stern et al.(1998) suggested a positive relationship between environment-related beliefs with altruistic and biospheric values and a negative relationship between the same type of beliefs with egoistic values.

Chua et al. (2016) argued that values orientation in terms of biospheric value, altruistic value, and egoistic value are important predictors of NEP. Altruistic values were the strongest predictor of both environmental beliefs and personal norms (Vanderploeg \& Lee 2019). Moreover, previous studies found that Altruistic values have a significant positive relation with Environmental beliefs (Vanderploeg \& Lee 2019; Whitley et al., 2016; De Groot and Steg, 2008; Stern et al.,1998; Karp, 1996; Stern and Dietz, 1994). However, a study by Liu et al. (2018) found non-significant relationships between altruistic values and NEP. In addition, Vanderploeg and Lee (2019) found no significant relationship between egoistic values and environmental beliefs. According to VBN theory, human values such as biospheric value, egoistic value, and altruistic values are expected to affect their beliefs. Thus, the hypotheses of this study are developed as follows:

H1: Altruistic values have a positive effect on environmental beliefs

H2: Egoistic values have a negative effect on environmental beliefs

H3: Biospheric values have a positive effect on environmental beliefs

Table 2. Summary of VBN and SDT theory used in e-waste and environmental research

\begin{tabular}{|c|c|c|c|c|c|c|}
\hline Author & Context & $\begin{array}{c}\text { Countr } \\
\mathbf{y}\end{array}$ & Respondents & $\begin{array}{l}\text { Theorie } \\
\text { s }\end{array}$ & IV & $\mathrm{V}^{\mathrm{D}}$ \\
\hline $\begin{array}{l}\text { Vanderploeg } \\
\text { \& Lee, } 2019\end{array}$ & $\begin{array}{c}\text { PEB in Craft } \\
\text { Business }\end{array}$ & USA & $\begin{array}{c}\text { Shop owners } \\
\text { \&managers }(275)\end{array}$ & $\mathrm{VBN}$ & $\begin{array}{l}\mathrm{AV}, \mathrm{EV}, \mathrm{CV}, \\
\mathrm{OCV}, \mathrm{EB}, \mathrm{PN}\end{array}$ & $\begin{array}{l}\text { POB, } \\
\text { BPB }\end{array}$ \\
\hline $\begin{array}{l}\text { Gkargkavouz } \\
\text { i et al., } 2019\end{array}$ & $\begin{array}{l}\text { Environmenta } \\
1 \\
\text { behaviour in a } \\
\text { private-sphere } \\
\text { context }\end{array}$ & Greece & $\begin{array}{c}\text { Individuals(1551 } \\
\text { ) }\end{array}$ & TPB, VBN & $\begin{array}{c}\text { BV,NEP,AC,AR,PN } \\
\text { HAB,ATT,SN,PBC, } \\
\text { ID }\end{array}$ & $\begin{array}{l}\text { INT, } \\
\text { PP }\end{array}$ \\
\hline $\begin{array}{l}\text { Li et al., } \\
2018\end{array}$ & $\begin{array}{l}\text { Municipal } \\
\text { solid waste } \\
\text { separation }\end{array}$ & China & Residents (341) & $\begin{array}{l}\text { Extended } \\
\text { VBN }\end{array}$ & $\begin{array}{c}\text { AV,BV,EV,AC, } \\
\text { AR,PN,GT,ED }\end{array}$ & INT \\
\hline
\end{tabular}




\begin{tabular}{|c|c|c|c|c|c|c|}
\hline Author & Context & $\begin{array}{l}\text { Countr } \\
\mathbf{y}\end{array}$ & Respondents & $\begin{array}{l}\text { Theorie } \\
\text { s }\end{array}$ & IV & V \\
\hline $\begin{array}{l}\text { Liu et al., } \\
2018\end{array}$ & $\begin{array}{l}\text { Public-Sphere } \\
\text { PEB }\end{array}$ & China & Students (1034) & VBN & $\begin{array}{l}\mathrm{AV}, \mathrm{BV}, \mathrm{EV}, \\
\mathrm{NEP}, \mathrm{PEPN}\end{array}$ & PSPB \\
\hline $\begin{array}{c}\text { Onel\& } \\
\text { Mukherjee, } \\
2017\end{array}$ & $\begin{array}{l}\text { Consumer's } \\
\text { Recycling }\end{array}$ & USA & Consumers(206) & $\begin{array}{c}\text { VBN, TPB, } \\
\text { TOA }\end{array}$ & $\begin{array}{c}\text { ATT, SN, PBC, } \\
\text { AV,BV,EV,EC,AC, } \\
\text { AR, PEPN }\end{array}$ & $\begin{array}{l}\text { INT, } \\
\text { PEB }\end{array}$ \\
\hline $\begin{array}{l}\text { Whitley et } \\
\text { al., } 2016\end{array}$ & $\begin{array}{c}\text { Sustainability } \\
\text { behaviours }\end{array}$ & USA & Students(1532) & VBN & VAL, BLF, NRM & BHV \\
\hline $\begin{array}{c}\text { Kiatkawsin\& } \\
\text { Han, } 2016\end{array}$ & $\begin{array}{l}\text { PEB of } \\
\text { Young } \\
\text { travellers }\end{array}$ & $\begin{array}{l}\text { South } \\
\text { Korea }\end{array}$ & $\begin{array}{c}\text { Young } \\
\text { travellers(538) } \\
\text { (University) }\end{array}$ & $\begin{array}{l}\text { VBN, } \\
\text { Expectancy } \\
\text { Theory }\end{array}$ & $\begin{array}{c}\text { AV, BV, EV } \\
\text { VAL, INS, EXP, } \\
\text { AC,AR,NEP,PEPN }\end{array}$ & INT \\
\hline $\begin{array}{c}\text { Chua et al., } \\
2016\end{array}$ & Agriculture & Malaysia & $\begin{array}{c}\text { Paddy } \\
\text { Farmers(277) }\end{array}$ & VBN & $\begin{array}{c}\text { AV,BV,EV, } \\
\text { NEP }\end{array}$ & PEPN \\
\hline $\begin{array}{l}\text { Cheung et } \\
\text { al., } 2016\end{array}$ & $\begin{array}{l}\text { Household } \\
\text { energy } \\
\text { Pro- }\end{array}$ & Hong Kong & Residents (1004) & MGB,SDT & $\begin{array}{c}\text { ATT,SN,PBC,NAE } \\
\text { PAE,DES,EXT,INT,P } \\
\text { B }\end{array}$ & $\begin{array}{l}\text { INT, } \\
\text { BHV }\end{array}$ \\
\hline $\begin{array}{c}\text { Lee \& Jeong, } \\
2018 \\
\end{array}$ & $\begin{array}{c}\text { environmental } \\
\text { Behaviour of } \\
\text { visitors }\end{array}$ & Korea & Visitors (222) & SDT & $\begin{array}{l}\text { IM, EM, PEDI, } \\
\text { LSM }\end{array}$ & PEB \\
\hline
\end{tabular}

(PSPB: Public-sphere pro-environmental behaviour, VAL: Valence, INS: Instrumentality, EXP: Expectancy, INT: Intention, AC: Ascription of Responsibility, AR: Awareness of Consequences, PPN: Pro-environmental Personal Norm, NEP: New Ecological Paradigm, EV: Egoistic Value, AV: Altruistic Value, BV: Biospheric Value, GT: Green trust, ED: Education, ID: Identity, HAB: Habit, PP: Personal Practice, TOA: Theory on effect, PEPN: Pro-environmental personal norm, MGB: Model of goal-directed behaviour, PAE: Positive anticipated emotions, NAE: Negative anticipated emotions, PB: Past behaviour, IM: Intrinsic motivation, EM: Extrinsic motivation, LSM: Leisure sports mania, PEDI: Pro-environmental destination image).

Table 2 represents the systematic literature review of the two main theories used in this study. This has helped in finding the research gap of this study.

\section{Environmental beliefs}

Environmental psychology informs us that individuals with positive environmental attitudes tend to be morally directed to behave in the spirit of correcting the negative consequences of human-environment interaction (Stern, 2000). Similarly, findings of the previous study also suggested that individuals, who possess awareness about the future of the planet, tend to perform pro-environmental behaviours (Dunlap et al., 2000). New Environmental Paradigm (NEP) was found to have a significant impact on Pro-environmental Personal Norm (PPN) (Liu et al., 2018). In a subsequent study, Vanderploeg and Lee (2019) demonstrated that environmental belief has a positive significant relationship with the personal norm. As a result, this study developed another hypothesis which is:

\section{H4: Environmental beliefs have a positive effect on personal norms.}

\section{Personal norm}

A number of prior researchers found personal norm has a significant relation with intention in the context of both private sphere and the public sphere (Gkargkavouzi et al., 2019; Liu et al., 2018; Wang et al., 2018; Onel \& Mukherjee, 2017). According to Kiatkawsin and Han (2017), Pro-environmental Personal Norm was found significantly related to intention to behave pro-environmentally while travelling. A similar study also found a significant relationship between personal norms and recycling behaviour (Vanderploeg \& Lee 2019; Onel \& Mukherjee, 2017). Similarly, in the area of municipal solid waste, the personal norm was found significantly related to separation intention (Li et al., 2018). So this study proposed another hypothesis which is:

\section{H5: Personal norms have a positive effect on e-waste separation intention.}

\section{Self-determination theory}

Self-determination theory deals with the motivation that stimulates individuals' inherent tendencies to behave in effective and healthy ways (Sweeney et al., 2014; Deci \& Ryan, 2000; Williams \& Deci, 1996; Deci et al., 1994; Deci \& Ryan, 1985). It defines six different ways in which motivated behaviour is regulated by a person. These types are categorized as motivation, external, introjection, identification, integration, and intrinsic regulation. The theory offers a framework to understand the relationships between motivation and PEB. It was chosen for two main reasons. Firstly, it 
has a significant and reliable association with PEB. Secondly, it provides specific predictions about how motivation will influence an individual's behaviours (Deci \& Ryan, 2008; Villacorta et al., 2003; Pelletier et al., 1998).

Technically, intrinsic motivation pertains to activities done "for their own sake," or for their inherent interest and enjoyment (Deci \& Ryan, 2000). Extrinsic motivation concerns behaviours done for reasons other than their inherent satisfaction. SDT entails four main types of extrinsic motivation. These vary based on whether the source of the regulation of behaviour is self-regulated, or in other words, more or less internalized (Deci \& Ryan, 2000). External regulation focuses on the behaviours that are determined by rewards and punishments imposed externally and both of these are a form of motivation typically experienced as controlled and non-autonomous. Introjected regulation undertakes extrinsic motivation that has been partially internalized in which behaviour is regulated by the internal rewards of self-esteem for success and by avoidance of anxiety, shame, or guilt for failure. Identified regulations take place when people recognize and accept the underlying value of behaviour, but have not yet fully integrated the behaviour with other aspects of their identity. Integrated regulation is considered the most complete expression of internalized extrinsic motivation given that it involves not only identifying with the importance of behaviours but also ensuring those identifications to be integrated with other aspects of the self.

According to Lee and Jeong (2018), intrinsic and extrinsic motivation have a positive significant relationship with pro-environmental behaviour. Similarly, Nguyen et al. (2018) reported a significant relationship between e-waste recycling intention and pro-environmental behaviour. Therefore, this study assumes that intrinsic motivation and extrinsic motivation will affect e-waste separation intention. Thus, the hypotheses proposed are as follows:

H6: Intrinsic motivations have a positive effect on e-waste separation intention.

H7: Extrinsic motivations have a positive effect on e-waste separation intention.

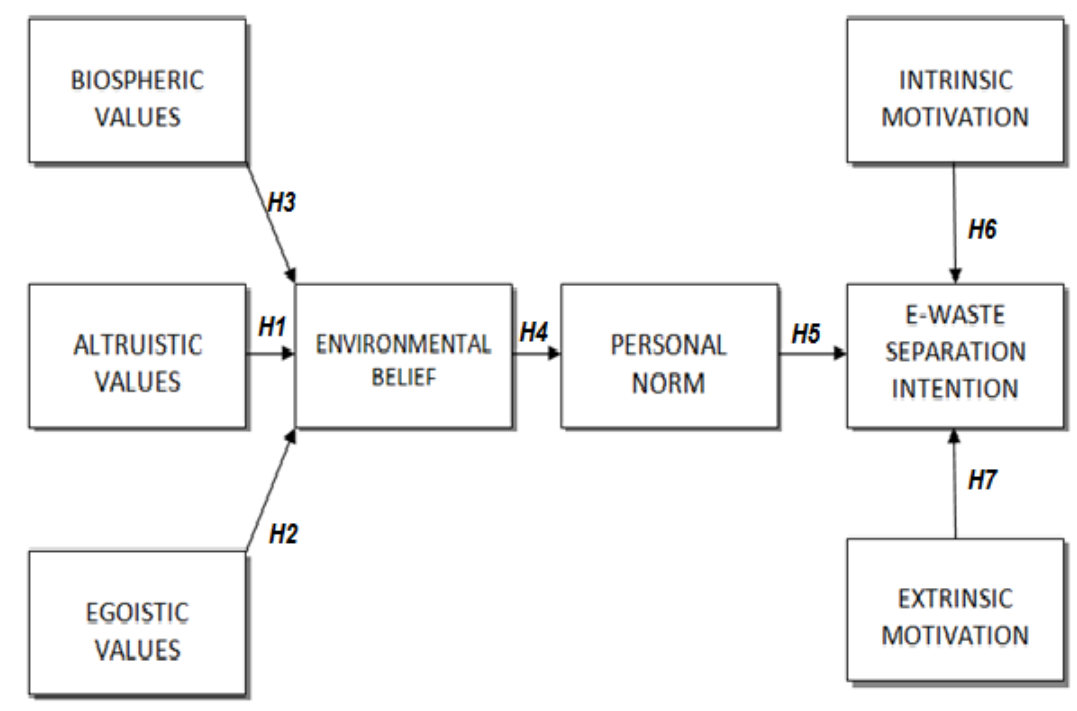

Figure1. Conceptual model

\section{METHODOLOGY}

This research will collect the data by designing structured questionnaires, which will be adapted from the earlier studies and administered among the electronic shop owners of Dhaka city in Bangladesh. A cross-sectional type of inquiry will be followed by the questionnaire in this study, meaning that the data will be collected at one point in time. Questionnaires will be prepared in two languages, i.e., English and Bangla, to generate a comfort zone for the respondents. Finally, the analysis of the research model will be subjected to the Partial Least Squares (PLS) through PLS 3.0 software.

\section{FINDINGS}

Based on the Value-Belief-Norm Theory, Self Determination Theory, and relevant literature in the body of knowledge, this paper presents an integrated conceptual model consisting of altruistic values, biospheric values, egoistic values, environmental belief, personal norm, intrinsic motivation, and external motivation, which are predicted to influence Ewaste separation intention in Bangladesh. This conceptual paper is the earliest article produced from the entire research. This paper first identifies the problem statement that triggers the research and portrays the research questions. Then, it 
critically analyzes the Value-Belief-Norm Theory and Self Determination Theory and reviews literature relevant to ewaste recycling to identify the literature gaps. Consequently, a conceptual model and corresponding propositions are presented.

\section{CONCLUSION}

This current study intends to reveal the key determinants that influence e-waste separation intention among small and medium electronic shop owners. It contributes to the current knowledge dedicated to clarifying the factors that contribute towards separation intention of e-waste, particularly in Bangladesh. The proposed conceptual model presents novelty as it incorporates the Value-Belief-Norm Theory and Self Determination Theory in an integrated framework to investigate the phenomenon of this study. On a practical level, this research highlights the key determinants affecting the separation intention, which practitioners need to consider when making e-waste management strategies and policies. This result will have important practical implications for organizations or firms to encourage the local electronic shop owners and manufacturing industry to revise their recycling process to compete in the local and global market strategically.

\section{REFERENCES}

Aich, N., Kordas, K., Ahmed, S. I., \& Sabo-Attwood, T. (2020). The Hidden Risks of E-Waste: Perspectives from Environmental Engineering, Epidemiology, Environmental Health, and Human-Computer Interaction. In Transforming Global Health,161-178 Springer, Cham.

Alam, M., \&Bahauddin, K. M. (2015). E-Waste In Bangladesh: Evaluating The Situation, Legislation And Policy And Way Forward With Strategy And Approach. Present Environment and Sustainable Development, 9(2), 25-46.

Andersson, L., Shivarajan, S., \&Blau, G. (2005). Enacting ecological sustainability in the MNC: A test of an adapted value-beliefnorm framework. Journal of business ethics, 59(3), 295-305.

Asibey, M. O., Lykke, A. M., \& King, R. S. (2020). Understanding the factors for increased informal electronic waste recycling in Kumasi, Ghana. International Journal of Environmental Health Research, 1-16.

Badgie, D. (2010). Solid Waste Management System in the Kanifing Municipal Council Area, The Gambia (Doctoral dissertation, Universiti Putra Malaysia).

Barr, S. (2007). Factors influencing environmental attitudes and behaviors: A UK case study of household waste management. Environment and behavior, 39(4), 435-473.

Bhat, V., \& Patil, Y. (2014). E-waste consciousness and disposal practices among residents of Pune city. Procedia-Social and Behavioral Sciences, 133, 491-498.https://doi.org/10.1016/j.sbspro.2014.04.216

Boldoczki, S., Thorenz, A., \&Tuma, A. (2020). The environmental impacts of preparation for reuse: A case study of WEEE reuse in Germany. Journal of Cleaner Production, 252, 119736.

Chua, K. B., Quoquab, F., Mohammad, J., Basiruddin, R., \&Phau, I. (2016). The Mediating Role of New Ecological Paradigm between Value Orientations and Pro-Environmental Personal Norm in the Agricultural Context. Asia Pacific Journal of Marketing and Logistics 28(2), 323-349.

Davis, G., Herat, S., 2010. Opportunities and constraints for developing asustainable E-waste management system at local government level inAustralia. Waste Manage. Res. 28 (8), 705-713.

Deci, E. L., \& Ryan, R. M. (1985). (1985b). Intrinsic motivation and self-determination in human behavior. New York: Plenum.

Deci, E. L., \& Ryan, R. M. (2000). Human needs and the self-determination of behavior. Psychological Inquiry, 11(4), $227-268$.

Deci, E. L., \& Ryan, R. M. (2008). Facilitating optimal motivation and psychological well-being across life's domains. Canadian psychology/Psychologiecanadienne, 49(1), 14.

Deci, E. L., Eghrari, H., Patrick, B. C., \& Leone, D. R. (1994). Facilitating internalization: The self-determination theory perspective. Journal of personality, 62(1), 119-142.

Dias P, Bernardes AM, Huda N (2018) Waste electrical and electronic equipment (WEEE) management: an analysis on the Australian e-waste recycling scheme. J Clean Prod 7(1), 750-764

Duygan, M., Meylan, G., 2015. Strategic management of WEEE inSwitzerland-combining material flow analysis with structural analysis. Resour.Conserv. Recycl. 103, 98-109.

Fornara, F., Pattitoni, P., Mura, M., \&Strazzera, E. (2016). Predicting intention to improve household energy efficiency: The role of value-belief-norm theory, normative and informational influence, and specific attitude. Journal of Environmental Psychology, $45,1-10$.

Fu, J., Zhang, H., Zhang, A., Jiang, G., 2018. E-waste recycling in China: a challenging field. Environ. Sci. Technol. 52 (12), 67276728.

Garcia, A.G., Roman-Moguel, G., Meraz-Cabrera, L., Acevedo, J., 2012. Policy optionsfor the management of end of life computers in Mexico. Clean Technol.Environ. Policy 14 (4), 657-667.

Gkargkavouzi, A., Halkos, G., \&Matsiori, S. (2019). Environmental behavior in a private-sphere context: Integrating theories of planned behavior and value belief norm, self-identity and habit. Resources, Conservation and Recycling, 148, 145-156.

Hai, H. T., Hung, H. V., \& Quang, N. D. (2017). An overview of electronic waste recycling in Vietnam. Journal of Material Cycles and Waste Management, 19(1), 536-544.

Henry, A. D., \& Dietz, T. (2012). Understanding environmental cognition. Organization \& Environment, 25(3), 238-258.

Herat, S., \&Agamuthu, P. (2012). E-waste: a problem or an opportunity? Review of issues, challenges and solutions in Asian countries. Waste Management \& Research, 30(11), 1113-1129.

Imran, M., Haydar, S., Kim, J., Awan, M.R., Bhatti, A.A., 2017. E-waste flows, resource recovery and improvement of legal framework in Pakistan. Resour. Conserv. Recycl.125, 131-138.

Islam, M. T., Abdullah, A. B., Shahir, S. A., Kalam, M. A., Masjuki, H. H., Shumon, R., \& Rashid, M. H. (2016). A public survey on knowledge, awareness, attitude and willingness to pay for WEEE management: Case study in Bangladesh. Journal of Cleaner Production, 137, 728-740. https://doi.org/10.1016/j.jclepro.2016.07.111 
Jakovcevic, A., \& Steg, L. (2013). Sustainable transportation in Argentina: Values, beliefs, norms and car use reduction. Transportation Research Part F: Traffic Psychology and Behaviour, 20, 70-79.https://doi.org/10.1016/j.trf.2013.05.005

Kabir, Z., \& Khan, I. (2020). Environmental impact assessment of waste to energy projects in developing countries: General guidelines in the context of Bangladesh. Sustainable Energy Technologies and Assessments, 37, https://doi.org/10.1016/j.seta.2019.100619

Kahhat, R., Kim, J., Xu, M., Allenby, B., Williams, E., Zhang, P., 2008. ExploringE-waste management systems in the United States. Resour. Conserv. Recycl. 52(7), 955-964.

Karim, R. T., Bari, N., \& Amin, M. A. (2014, September). E-waste Management in Bangladesh. In 2nd International Conference on Green Energy and Technology (pp. 104-109). IEEE.

Kiatkawsin, K., \& Han, H. (2017). Young travelers' intention to behave pro-environmentally: Merging the value-belief-norm theory and the expectancy theory. Tourism Management, 59, 76-88.

Kilbourne, W., \& Pickett, G. (2008). How materialism affects environmental beliefs, concern, and environmentally responsible behavior. Journal of Business Research, 61(9), 885-893.

Kim, H., Lee, S., \& Yang, K. (2015). The heuristic-systemic model of sustainability stewardship: Facilitating sustainability values, beliefs and practices with corporate social responsibility drives and eco-labels/indices. International Journal of Consumer Studies, 39, 249-260.

Kim, M., Jang, Y.C., Lee, S., 2013. Application of Delphi-AHP methods to select thepriorities of WEEE for recycling in a waste management decision-making tool.J. Environ. Manage. 128, 941-948.

Lee, W., \&Jeong, C. (2018). Effects of pro-environmental destination image and leisure sports mania on motivation and proenvironmental behavior of visitors to Korea's national parks. Journal of Destination Marketing \& Management, 10, 25-35.

Li, J. X., Huang, C., Zhu, Y., \& Huang, S. (2012). WEEE management in Chongqing, China: status and strategies. In Advanced Materials Research414, 39-44.

Li, J.P., 2011. Opportunities in action: the case of the US Computer TakeBackCampaign. Contemp. Polit. 17 (3), $335-354$.

Li, L., Yue, G., Xinquan, G., Yingmei, Y., Hua, C., Jianping, H., \& Jian, Z. (2018). Exploring the residents' intention to separate MSW in Beijing and understanding the reasons: An explanation by extended VBN theory. Sustainable cities and society, 37, 637648.https://doi.org/10.1016/j.scs.2017.11.036

Liu, X., Zou, Y., \& Wu, J. (2018). Factors influencing public-sphere pro-environmental behavior among Mongolian college students: A test of value-belief-norm theory. Sustainability, 10(5), 1384.

Madrigal-Arias, J. E., Argumedo-Delira, R., Alarcón, A., Mendoza-López, M., García-Barradas, O., Cruz-Sánchez, J. S., ... \& JiménezFernández, M. (2015). Bioleaching of gold, copper and nickel from waste cellular phone PCBs and computer goldfinger motherboards by two Aspergillus nigerstrains. Brazilian Journal of Microbiology, 46(3), 707-713.

Mahmud, I., Sultana, S., Rahman, A., Ramayah, T., \& Cheng Ling, T. (2020). E-waste recycling intention paradigm of small and medium electronics store managers in Bangladesh: An S-O-R perspective. Waste Management \& Research, DOI: $10.1177 / 0734242 X 20914753$

Manomaivibool, P., 2009. Extended producer responsibility in a non-OECD context: the management of waste electrical and electronic equipment in India. Resour. Conservat. Recycl. 53 (3), 136e144.

Manomaivibool, P., Vassanadumrongdee, S., 2011. Extended producerresponsibility in Thailand prospects for policies on waste electrical andelectronic equipment. J. Ind. Ecol. 15 (2), 185-205.

Masud, M. H., Akram, W., Ahmed, A., Ananno, A. A., Mourshed, M., Hasan, M., \&Joardder, M. U. H. (2019). Towards the effective E-waste management in Bangladesh: a review. Environmental Science and Pollution Research, 26(2), 1250-1276.

Menikpura, S.N.M., Santo, A., Hotta, Y., 2014. Assessing the climate co-benefitsfrom waste electrical and electronic equipment (WEEE) recycling in Japan. J.Clean. Prod. 74, 183-190.

Nduneseokwu, C. K., Qu, Y., \&Appolloni, A. (2017). Factors influencing consumers' intentions to participate in a formal e-waste collection system: A case study of Onitsha, Nigeria. Sustainability, 9(6), 881.

Nordlund, A. M., \&Garvill, J. (2002). Value structures behind proenvironmentalbehavior. Environment and Behavior, 34(6), 740-756.

Nordlund, A. M., \&Garvill, J. (2003). Effects of values, problem awareness, and personal norm on willingness to reduce personal car use. Journal of Environmental Psychology, 23(4), 339-347.

Ofstad, S. P., Tobolova, M., Nayum, A., \&Klöckner, C. A. (2017). Understanding the mechanisms behind changing people's recycling behavior at work by applying a comprehensive action determination model. Sustainability, 9(2), 204.

Oleszek, S., Grabda, M., Nakamura, T., Buekens, A., 2018. Upcycling of e-waste plastics containing brominated flame retardants into valuable carbon material. 2018 Advances in Science and Engineering Technology International Conferences (ASET) 1-4.

Onel, N., \& Mukherjee, A. (2017). Why do consumers recycle? A holistic perspective encompassing moral considerations, affective responses, and self-interest motives. Psychology \& Marketing, 34(10), 956-971.

Oteng-Ababio, M. (2012). Electronic waste management in Ghana-Issues and practices. Sustainable Development-Authoritative and Leading Edge Content for Environmental Management, 600.

Pandey, P., Govind, M., 2014. Social repercussions of e-waste management in India: a study of three informal recycling sites in Delhi. Int. J. Environ. Stud. 71 (3), 241-260.

Papagiannakis, G., \&Lioukas, S. (2012). Values, attitudes and perceptions of managers as predictors of corporate environmental responsiveness. Journal of environmental management, 100, 41-51.

Pariatamby, A., Victor, D., 2013. Policy trends of E-waste management in Asia. J.Mater. Cycles Waste Manage.15 (4), $411-419$.

Pelletier, L. G., Tuson, K. M., Green-Demers, I., Noels, K., \& Beaton, A. M. (1998). Why are you doing things for the environment? The motivation toward the environment scale (mtes) 1. Journal of applied social psychology, 28(5), 437-468.

Queiruga, D., Benito, J.G., Lannelongue, G., 2012. Evolution of the electronic wastemanagement system in Spain. J. Clean. Prod. 24, $56-65$.

Ramayah, T. and Rahbar, E. (2013), "Greening the environment through recycling: an empirical study", Management of Environmental Quality, 24 (6), 782-801.

San, Q., Muntaha, C., \& Hossain, M. M. (2016). E-waste Generation from Mobile Phone and its Recovery Potential in Bangladesh. Journal of Environmental Science and Natural Resources, 9(1), 91-94.

Schwartz, S. H. (1992). Universals in the content and structure of values: Theoretical advances and empirical tests in 20 countries. Advances in Experimental Social Psychology, 25(1), 1-65. 
Schwarzer, S, Bono, AD, Peduzzi, P, Giuliani, G, Kluser, S (2005) E-waste, the hidden side of IT equipment's manufacturing and use. UNEP Early Warning on Emerging Environmental Threats No. 5. Switzerland: United Nations Environment Program

Shaikh, S., Thomas, K., \& Zuhair, S. (2020). An exploratory study of e-waste creation and disposal: Upstream considerations. Resources, Conservation and Recycling, 155, 104662.

Steg, L., Dreijerink, L., \&Abrahamse, W. (2005). Factors influencing the acceptability of energy policies: A test of VBN theory. Journal of Environmental Psychology, 25, 415-425.

Stern, P. C. (2000). Towards a coherent theory of environmentally significant behavior. Journal of Social Issues, 56(3), 407-424

Stern, P. C., \& Dietz, T. (1994). The value basis of environmental concern. Journal of Social Issues, 50(3), 65-84.

Stern, P. C., Dietz, T., Abel, T. D., Guagnano, G. A., \&Kalof, L. (1999). A value-beliefnorm theory of support for social movements: The case of environmentalism. Human Ecology Review, 6(2), 81-95.

Sweeney, J. C., Webb, D., Mazzarol, T., \&Soutar, G. N. (2014). Self-determination theory and word of mouth about energy-saving behaviors: an online experiment. Psychology \& Marketing, 31(9), 698-716.

Nguyen, H. T. T., Hung, R. J., Lee, C. H., \& Nguyen, H. T. T. (2018). Determinants of residents' E-Waste recycling behavioral intention: a case study from Vietnam. Sustainability, 11(1), 1-24.

Vanderploeg, J., \& Lee, S. E. (2019). Factors influencing pro-environmental behaviors in craft businesses. Clothing and Textiles Research Journal, 37(1), 51-65.

Veenstra, A., Wang, C., Fan, W.J., Ru, Y.H., 2010. An analysis of E-waste flows inChina. Int. J. Adv. Manuf. Technol. 47 (5-8), $449-$ 459.

Villacorta, M., Koestner, R., \&Lekes, N. (2003). Further validation of the motivation toward the environment scale. Environment and Behavior, 35(4), 486-505.

Wagner, T.P., 2009. Shared responsibility for managing electronic waste: a casestudy of Maine, USA. Waste Manage. 29 (12), $3014-$ 3021.

Wang, Z., Guo, D., Wang, X., Zhang, B., \& Wang, B. (2018). How does information publicity influence residents' behaviour intentions around e-waste recycling? Resources, Conservation and Recycling, 133, 1-9. https://doi.org/10.1016/j.resconrec.2018.01.014

Whitley, C. T., Takahashi, B., Zwickle, A., Besley, J. C., \&Lertpratchya, A. P. (2018). Sustainability behaviors among college students: An application of the VBN theory. Environmental education research, 24(2), 245-262.

Widmer, R., Oswald-Krapf, H., Sinha-Khetriwal, D., Schnellmann, M., \&Böni, H. (2005). Global perspectives on e-waste. Environmental impact assessment review, 25(5), 436-458.

Williams, G. C., \& Deci, E. L. (1996). Internalization of biopsychosocial values by medical students: a test of self-determination theory. Journal of personality and social psychology, 70(4), 767.

Xavier LH, Adenso-Díaz B (2015) Decision models in e-waste management and policy: a review. Decision Models in Engineering and Management, Springer, 271-291 DOI https://doi.org/10.1007/978-3-319-11949-6_15

Ylä-Mella, J., Keiski, R. L., \&Pongrácz, E. (2015). Electronic waste recovery in Finland: Consumers’ perceptions towards recycling and re-use of mobile phones. Waste management, 45, 374-384. https://doi.org/10.1016/j.wasman.2015.02.031.

Yu, L., He, W., Li, G., Huang, J., \& Zhu, H. (2014). The development of WEEE management and effects of the fund policy for subsidizing WEEE treating in China. Waste management, 34(9), 1705-1714.

Step Initiative. (2014). Solving the E-Waste Problem (Step) White Paper: One Global Definition of E-waste. Bonn, Germany. Step, 3576. Retrieved from http://www.step initiative.org/files/step/_documents/StEP_WP_OneGlobalDefinitionofEwaste_20140603_amended.pdf.

Borthakur, A., \& Govind, M. (2017). Emerging trends in consumers' E-waste disposal behaviour and awareness: A worldwide overview with special focus on India. Resources, Conservation and Recycling, 117, $102-113$. https://doi.org/10.1016/j.resconrec.2016.11.011

Dunlap, R. E., Van Liere, K. D., Mertig, A. G., \& Jones, R. E. (2000). New trends in measuring environmental attitudes: measuring endorsement of the new ecological paradigm: a revised NEP scale. Journal of social issues, 56(3), 425-442.

De Groot, J. I., \& Steg, L. (2008). Value orientations to explain beliefs related to environmental significant behavior: How to measure egoistic, altruistic, and biospheric value orientations. Environment and Behavior, 40(3), 330-354.

Liu, Q., Li, K. Q., Zhao, H., Li, G., \& Fan, F. Y. (2009). The global challenge of electronic waste management. Environmental Science and Pollution Research, 16(3), 248-249.

Stern, P. C., Dietz, T., \& Guagnano, G. A. (1998). A brief inventory of values. Educational and psychological measurement, 58(6), 984-1001.

Alam, M., \& Bahauddin, K. M. (2015). E-Waste In Bangladesh: Evaluating The Situation, Legislation And Policy And Way Forward With Strategy And Approach. Present Environment and Sustainable Development, 9(2), 25-46.

Karp, D. G. (1996). Values and their effect on pro-environmental behavior. Environment and behavior, 28(1), 111-133.

Steg, L., Bolderdijk, J. W., Keizer, K., \& Perlaviciute, G. (2014). An integrated framework for encouraging pro-environmental behaviour: The role of values, situational factors and goals. Journal of Environmental psychology, 38, 104-115.

Ture, R. S., \& Ganesh, M. P. (2014). Understanding pro-environmental behaviours at workplace: Proposal of a model. Asia-Pacific Journal of Management Research and Innovation, 10(2), 137-145.

Choi, H., Jang, J., \& Kandampully, J. (2015). Application of the extended VBN theory to understand consumers' decisions about green hotels. International Journal of Hospitality Management, 51, 87-95.

Nnorom, I. C., \& Osibanjo, O. (2008). Overview of electronic waste (e-waste) management practices and legislations, and their poor applications in the developing countries. Resources, conservation and recycling, 52(6), 843-858. 


\section{AUTHORS' BIOGRAPHY}

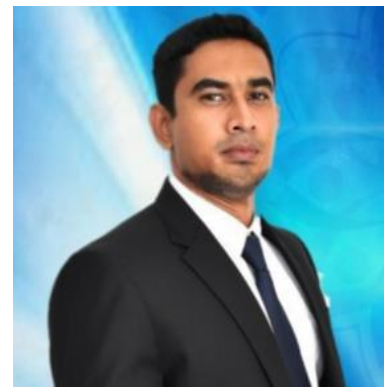

\section{Ashikur Rahman}

Ashikur Rahman is a PhD candidate at the Graduate School of business, Universiti Sains Malaysia. He completed his Master of Business Administration from Southeast University, Bangladesh. Before that, he completed his Bachelor of Business Administration from United International University, Bangladesh. His research interest concerns e-waste recycling.

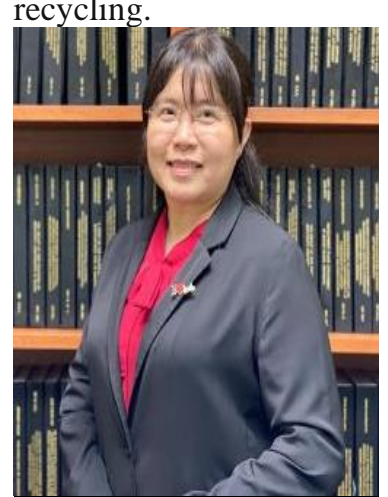

\section{Dr. Teoh Ai Ping}

Dr. Teoh Ai Ping is a senior lecturer at University Sains Malaysia. She holds the qualifications of Doctor of Business Administration, Master of Science in Information Technology and Bachelor of Accountancy (Hons.).Dr. Teoh was a pioneer academic and Deputy Dean in School of Business and Administration of a private University.

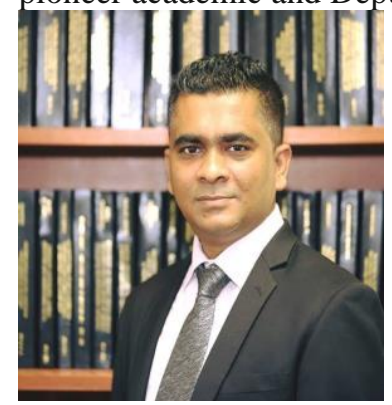

\section{Dr. Imran Mahmud}

Dr. Imran Mahmud is currently working as Head and Associate Professor at Department of Information Technology \& Management at Daffodil International University, Bangladesh. Previously, Dr. Imran worked as a senior lecturer at Universiti Sains Malaysia. He completed his PhD from Universiti Sains Malaysia and Masters from University of Hertfordshire, UK. 